\title{
Supremacy, direct effect and consistent interpretation-tools for an effective and uniform application of European Union law?
}

\author{
Tadeusz Ereciński
}

Published online: 3 November 2010

(C) The Author(s) 2010. This article is published with open access at Springerlink.com

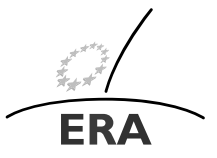

EUROPÄISCHE RECHTSAKADEMIE ACADEMY OF EUROPEAN LAW ACADEMIE DE DROIT EUROPEEN ACCADEMIA DI DIRITTO EUROPEO TRIER - TREVES - TREVIRI

\begin{abstract}
This article discusses the tools applied by Polish courts to achieve the effective and uniform application of European Union law. It cites and analyses relevant case law of the Polish Supreme Court assuring the supremacy and direct effect of European Union law, for example, European Union directives on consumer law.
\end{abstract}

Keywords Principle of supremacy · Consistent interpretation of European Union law $\cdot$ Polish courts $\cdot$ Consumer law $\cdot$ Industrial property law

More than six years of Polish membership of the European Union have now passed since 1 May 2004, which gives the opportunity to make some observations on the use by the Polish Supreme Court of tools for an effective and uniform application of European Union law.

The Supreme Court participates — as a European Union court-in the fulfillment by Poland of its duty to take appropriate measures, general or particular, to ensure fulfillment of the obligations arising out of the Treaties or resulting from the acts of the institutions of the Union, an obligation now provided for by Article 4 paragraph 3 of the Treaty on European Union).

The Polish courts are fully conscious of their obligation to guarantee the full effectiveness of European Union law and the necessity to refuse to apply provisions of national law which are contrary to European Union law, without the necessity to wait

This paper is based on a contribution given at the conference on Effective Judicial Protection in European Union Law, organised by the Academy of European Law Trier in cooperation with the French National Judicial School (ENM) and the French Court of Cassation on 15-16 February 2010 in Paris.

T. Ereciński (凶)

Supreme Court of the Republic of Poland, Pkac Krasinskich 2/4/6, 00-951 Warsaw 41, Poland e-mail: ssncte@sn.pl 
for a formal removal of them from the legal system. Nevertheless, only a few Polish Supreme Court judgments have concerned the principles of supremacy and direct effect.

They show however that the Supreme Court has extensively considered the scope of the supremacy principle. The Court has applied it in the context both of primary and of secondary European Union law. It has given direct effect to Article 28 of the EC Treaty (now Article 34 of the Treaty on the Functioning of the European Union) prohibiting quantitative restrictions on imports and measures having equivalent effect. Insofar as concerns secondary law, the Court has given direct effect to measures in regulations and directives alike. The Court has held contracts granting the Polish fish processing industry with compensation for temporary cessation of activities in order to protect aquatic resources contrary to a 1999 Council Regulation laying down the detailed rules and arrangements regarding Community structural assistance in the fisheries sector. ${ }^{1}$ Several provisions of directives have been given direct effect in labour law cases. In one of them the Court held that a then-European Community rule prohibiting sex discrimination, then given expression by Article 4 of the 1978 Council Directive on the progressive implementation of the principle of equal treatment for men and women in matters of social securities, could be applied directly and required the same right to an early retirement pension for orchestra conductors who were men as for conductors who are women. ${ }^{2}$ In another case, concerning medical duties, the Supreme Court held that the computation of employee working time has to be done with regard to the 1993 Council Directive concerning certain aspects of the organization of working time. ${ }^{3}$ This decision resulted in the possibility of deriving employee rights against public employers directly from the directive. The Polish courts are however required to have regard to the point that the direct effect relates only to provisions which are clear, precise, unconditional and confer rights on individuals.

The case-law of the Court of Justice of the European Union shows that the efficiency principle affects national laws further than is justified by its objectives and function. As a result, this principle gradually "overwrites" the supremacy principle in some fields. Supremacy still plays a crucial role in resolving conflicts between national law and European Union law, whereas the efficiency principle is a mechanism - a tool—rendering possible the controlling of the conformity of national law with European Union law. The refusal to apply a national rule inconsistent with European Union law may be unsatisfactory for a person seeking protection of his or her right rooted in European Union law.

The efficiency principle is not superior to supremacy in general (a priori), however a court may apply the efficiency principle instead of the supremacy principle when this is justified by the circumstances of a given case. The efficiency principle includes, to a certain extent, the supremacy principle. However it is impossible to conclude in abstracto which one of them is superior-in one case the efficiency principle may prevail, while in other it is the supremacy principle.

\footnotetext{
${ }^{1}$ I CSK 239/08.

${ }^{2}$ I UK 182/07.

${ }^{3}$ I PK 263/05.
} 
A national court is obliged to apply both principles: efficiency and supremacy. In a given case they might be applied at different stages of review. First, the court has to interpret national law in conformity with a directive regulating the same issue (which involves the supremacy principle). Secondly, if this is not possible, the court will have to look for other solutions (tools) to achieve the ends of European Union law (which involves the efficiency principle).

In the analysed judgment, the Supreme Court did not limit the obligation to interpret national law in the light of a directive's meaning and objectives in order to eliminate a conflict between national and European provisions, but rather emphasised the role of European norms in shaping national laws.

The Supreme Court has quite broad experience in the field of the indirect effect of European Union law, and thus in ensuring the consistent interpretation of Polish legal provisions with European Union law, assuming that the limit to this is contra legem interpretation. Consistent interpretation has been applied by Polish courts to pre-accession cases too. In most of them the point of reference for the pro-European interpretation was the content and the aim of European Community directives (although the duty of consistent interpretation concerns also other European Union legal acts).

An important group of such cases is composed by cases concerning unfair contract terms settled in the Polish civil code as a result of the transposition of the Council Directive of 1993 on unfair terms in consumer contracts. ${ }^{4}$ Particularly broad reasons for the necessity of consistent interpretation have been put forward by the Supreme Court in a resolution of July 13, 2006, ${ }^{5}$ where it decided that the use of contract terms similar to those considered forbidden on the basis of a valid judgment by the Court of Competition and Consumer Protection and entered on the register of such terms can be considered on the part of another entrepreneur to be a practice violating collective consumer interests and that such a registration means the prohibition of using this contract clause by all legal persons, and not merely by the person whose case has been considered in the judgment which is the basis for the registration. The Court emphasised that interpretation of the provisions of the Polish law on competition and consumer protection and of the code of civil procedure had to be carried out in this case taking into account the content and the aim of the 1988 directive on injunctions for the protection of consumers' interests and of the 1993 directive on unfair terms in consumer contracts. The interpretation had to be consistent with directives even if the facts of the case occurred before the date of Polish accession. There was only a different legal basis for such a duty. In the case of facts occurring before this moment, the obligation of the pro-European interpretation had the nature of an international law duty and was based on the Europe Agreement of 1991 which established an association, and which entered into force in 1994. In these cases the Polish courts had no right to refer questions for a preliminary ruling to the European Court of Justice. In cases relating to facts which occurred after Polish accession, the obligation of consistent interpretation was European in nature and had its foundations in what

${ }^{4}$ I CKN 308/01, IV CSK 200/06.

${ }^{5}$ III SZP 3/06. 
is now Article 4(3) of the Treaty on European Union and in the judgments of the European Court of Justice.

The Supreme Court has taken a similar position in a copyright law case, considering that the Polish Act on copyright and related rights of 1994, even in its preaccession version should respect the content and the aim of the directive of 1993 on the coordination of certain rules concerning copyright and rights related to copyright applicable to satellite broadcasting and cable retransmission. ${ }^{6}$

There is a large number of judgments concerning the consistent interpretation of the Polish law on industrial property of 2000 with the 1998 directive on approximation of the laws of the Member States relating to trade marks. The Supreme Court has extensively cited the Court of Justice and Court of First Instance judgments concerning this directive and the 1993 regulation on the Community trade mark, because a lot of notions in both acts are similar. As an example, the Supreme Court has used the consistent interpretation doctrine in two cases defining the repute of a trade mark. ${ }^{7}$

In several cases the Supreme Court has required the consistent interpretation of national provisions concerning relations between private individuals in the context of VAT directives. ${ }^{8}$

The Supreme Court has refused however to apply consistent interpretation in a case concerning radio sponsorship considering that the Council directive of 1989 on "television without frontiers" was related only to television and not to radio, so that there was no basis for its application in the case at issue for the purpose of the interpretation of the Polish Broadcasting Act. ${ }^{9}$

The Supreme Court refused to require the consistent interpretation of the provisions of the Polish code of civil procedure on recognition of foreign judgments with the Treaty norms (viz., Article 61c, Article 65 and Article 293 Indent 4 of the EC Treaty), because they define only tasks and competences of the Communities in the scope of the judicial cooperation in civil matters. ${ }^{10}$

In another case consistent interpretation related to the framework directive of 2002 on a common regulatory framework for electronic communications networks and services. The Supreme Court had to rule on the possibility of appealing against a decision of the President of the Office of Telecommunications and Post which confirmed the absence of an effective competition on one of telecommunication markets. For this purpose the Supreme Court applied an interpretation consistent with European law of the Polish telecommunication law and of the code of civil procedure. The Court considered that although Article 4 of the framework directive was not a directly effective provision, because it was not unconditional, so that it could not be the basis for an appeal, Polish provisions should nevertheless be interpreted in a way that would guarantee the right to appeal expressed by this directive. Any other interpretation would eliminate the right to access to justice. ${ }^{11}$

\footnotetext{
${ }^{6}$ IV CSK 303/06.

${ }^{7}$ III CK 160/05, II CSK 428/06.

${ }^{8}$ III CSK 448/06, V CSK 4/07.

${ }^{9} \mathrm{I}$ CNP $41 / 06$.

${ }^{10}$ I CSK 159/09.

${ }^{11}$ III SK 23/07.
} 
In practice the Supreme Court has applied consistent interpretation in some criminal cases. ${ }^{12}$ The most important tool of judicial cooperation among European Union member states in criminal matters are framework decisions-which do not have direct effect. However they are applied as a model for consistent interpretation. The Supreme Court has decided for instance that in surrendering a person requested by an European Arrest Warrant in order to facilitate the conduct of criminal proceedings against this person on the territory of another European Union member state the provisions of the issuing state and not of the executing state should be applied and that they should be interpreted considering the content of the 2002 Council framework decision on the European Arrest Warrant and the surrender procedures between Member States. ${ }^{13}$

The judgments mentioned above, in particular those applying consistent interpretation, show that the process of the implementation of directives is not perfect, because many interpretative doubts exist concerning national provisions transposing directives. The legislative defects of Polish national provisions must be "repaired" by courts applying — as far as is possible — consistent interpretation. Polish law has been adapting to compatibility with the European Union law in a rather hurried way and now Polish courts have to struggle with the results. Since the coming into existence of the Constitutional Tribunal in 1985 and the entry into force of the new Constitution of 1997 national judges are quite familiar with the situation of where legal provisions are under scrutiny from the point of view of conformity with superior normative acts. They then apply European Union law, especially that they should take into consideration the responsibility provided by the Constitution for any harm done by an action of an organ of public authority contrary to law, including the incorrect application of the European Union law in the context of direct and indirect effect (consistent interpretation). The Courts are however rather prudent, because in borderline cases they are more disposed to apply national provisions and to consider European Union law only as point of reference for consistent interpretation than to decide in a more categorical way that European Union law has a direct effect, and in so doing to leave out national law.

It is also important to notice that the European Union law itself-extremely extensive, interfering deeply in national law and very dynamic_creates a system very difficult to effective and uniform application. A good example is European Union consumer law, which because of its incoherence has had to be consolidated at the European Union level and it is already implemented in the Member States law systems and national courts apply it with all the imperfection weight. The challenge for the national courts is to use European Court of Justice judgments that provide an interpretation of the European Union law, but sometimes it is rather difficult to foresee it at the moment of the transposition of the European Union provisions-sometimes very general. Furthermore the overwhelming majority of European Court of Justice judgments adopted before Polish accession have not yet been translated into Polish. Therefore the question of the effective and uniform application of European Union

\footnotetext{
${ }^{12}$ I KZP 21/06, I KZP 30/08.
}

${ }^{13}$ I KZP 21/06. 
law by national courts is often at the same time the question on the quality and certainty of the European Union law and its cohesion with the national law. The tools of supremacy, direct effect and consistent interpretation accessible to national judges do not resolve all the problems generated in the European Union legislative process, by the creative interpretation of the European Court of Justice and by implementation of European law norms into national law.

Nevertheless it has to be said that the application by the Polish Supreme Court of European Union law rarely gives rise to doubts involving the necessity to request a preliminary ruling under Article 267 of the Treaty on the Functioning of the European Union. Up to now, the Labour Law, Social Security and Public Affairs Chamber of the Supreme Court has requested the European Court of Justice to make a preliminary ruling on four occasions. ${ }^{14}$ It is noticeable that a preliminary ruling is now more often requested by parties who sometimes provide a large number of arguments for it. In most cases the Supreme Court does not agree that there are doubts justifying the question. Although the Court is not bound by the parties' request, it nevertheless gives reasons for refusing to refer the question. ${ }^{15}$

Open Access This article is distributed under the terms of the Creative Commons Attribution Noncommercial License which permits any noncommercial use, distribution, and reproduction in any medium, provided the original author(s) and source are credited.

\footnotetext{
${ }^{14}$ III SK 27/08, III SK 2/09, I UK 344/08, III SK 16/08. Three of these already had a European Court of Justice reference number on 18 January, 2010.

${ }^{15}$ I CK 207/05, I CNP 41/06, I CSK 70/08, I CSK175/08. 